\title{
Gender and emotional intelligence as predictors of career adaptability in the Department of Water and Sanitation in South Africa
}

\begin{tabular}{|c|c|}
\hline \multicolumn{2}{|c|}{$\begin{array}{l}\text { Authors: } \\
\text { Nisha Harry }{ }^{1} \text { ( } \\
\text { Thapelo Malepane }{ }^{1}\end{array}$} \\
\hline \multicolumn{2}{|c|}{$\begin{array}{l}\text { Affiliations: } \\
{ }^{1} \text { Department of Industrial } \\
\text { and Organisational } \\
\text { Psychology, School of } \\
\text { Management Sciences, } \\
\text { University of South Africa, } \\
\text { Pretoria, South Africa }\end{array}$} \\
\hline \multicolumn{2}{|c|}{$\begin{array}{l}\text { Corresponding author: } \\
\text { Nisha Harry, } \\
\text { harryn@unisa.ac.za }\end{array}$} \\
\hline \multicolumn{2}{|c|}{$\begin{array}{l}\text { Dates: } \\
\text { Received: } 27 \text { July } 2020 \\
\text { Accepted: } 03 \text { Feb. } 2021 \\
\text { Published: } 31 \text { Aug. } 2021\end{array}$} \\
\hline \multicolumn{2}{|c|}{$\begin{array}{l}\text { How to cite this article: } \\
\text { Harry, N., \& Malepane, T. } \\
\text { (2021). Gender and } \\
\text { emotional intelligence as } \\
\text { predictors of career } \\
\text { adaptability in the } \\
\text { Department of Water and } \\
\text { Sanitation in South Africa. } \\
\text { SA Journal of Industrial } \\
\text { Psychology/SA Tydskrif vir } \\
\text { Bedryfsielkunde, 47(0), } \\
\text { a1828. https://doi.org/ } \\
\text { 10.4102/sajip.v47i0.1828 }\end{array}$} \\
\hline \multicolumn{2}{|c|}{$\begin{array}{l}\text { Copyright: } \\
\text { (C) 2021. The Authors. } \\
\text { Licensee: AOSIS. This work } \\
\text { is licensed under the } \\
\text { Creative Commons } \\
\text { Attribution License. }\end{array}$} \\
\hline \multicolumn{2}{|l|}{ Read online: } \\
\hline 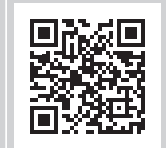 & $\begin{array}{l}\text { Scan this QR } \\
\text { code with your } \\
\text { smart phone or } \\
\text { mobile device } \\
\text { to read online. }\end{array}$ \\
\hline
\end{tabular}

Orientation: The Water and Sanitation Department in South Africa has undergone changes resulting in diminished job security, reduced employment and evolving technology, thus compelling employees to adjust to and cope continuously with these changes. Employees are now more responsible than ever before for developing self-regulatory resources, to remain employable.

Research purpose: The study aimed to examine the role of gender and emotional dimensions in career adaptability among employees of the Department of Water and Sanitation, South Africa.

Motivation for the study: There is a paucity of research into the way in which gender and emotional intelligence act as predictors of career adaptability, specifically in a public sector service.

Research approach/design and method: A quantitative, cross-sectional research design was conducted on a convenience sample $(N=160)$ of staff employed by the Water and Sanitation Department in South Africa.

Main findings: The bivariate correlation revealed significant associations between overall emotional intelligence, with career adaptability and it sub-dimensions. Stepwise hierarchical analysis revealed significant associations between gender, and emotional intelligence with the outcome variable. The Mann-Whitney $U$ test was used to predict the research objective of the study.

Practical/managerial implications: The study results emphasised the importance of emotional intelligence and career adaptabilities as important meta-competencies in helping employees to respond to career changes and to craft sustainable careers.

Contribution/value add: The results also highlighted the strengths of developmental areas for both women and men in developing their emotional intelligence and career adaptability.

Keywords: career adaptability; emotional intelligence; gender; employees; South Africa.

\section{Introduction}

People generally regard employment as an important aspect of their everyday life. However, several challenges exist in the work environment that may impact both their productivity and their health. Accordingly, it is vital that individuals are able to adapt resourcefully in a changing environment (Brown \& Lent, 2016). There are various challenges that affect employees in the public sectors, for example, in the Water and Sanitation Department in South Africa, employees are exposed to precarious situations such as poor governance, volatile economic conditions, poor service delivery, ambiguous job roles and career uncertainty (Brown \& Lent, 2016). This has resulted in employees acquiring new skill and competencies to enable them to contribute to the global business market. Career adaptability may be regarded as psychosocial resources and a cardinal construct useful for having a better understanding of vocational behaviour in which individuals continually adapt throughout life in the ever-changing personal needs and environmental demands (Ambiel, De Carvalho, Martins, \& Tofoli, 2016; Duffy, 2010; Savickas, 2012; Tolentino et al., 2014).

As evidenced in research by Lee (2019), emotional intelligence plays an important role in the public sector with individuals who display emotional intelligence in such work environments indicating emotional awareness. Citizens expect high quality service delivery from the 
public sector and emotionally intelligent leaders may ensure a rational outlook when it comes to decisionmaking (Lee, 2019).

There has been very little research conducted in the Water and Sanitation Department in South Africa regarding gender, emotional intelligence and career adaptability.

\section{Literature review}

\section{The relationship between career adaptability, emotional intelligence and gender}

The world is constantly undergoing change and, as a result, many employees are faced with several challenges, including diminished job security, reduced employment, evolving technology and pandemics (Ineson, Benke, \& Laszlo, 2013). As evidenced in research, the psychological contract of predictability, stability and permanence has evolved into a contract that defines casual, flexible and continuous changes, the value of skills and competence and temporary work (Ferreira, 2012; Maree, 2013; Tolentino et al., 2014; Zacher, Ambiel, \& Noronha, 2015).

Both globalisation and demographic change are becoming more diverse in organisations and, thus, it is imperative that employees are skilled to ensure they possess the knowledge required to enable them to contribute to an organisation's overall performance. Career adaptability is defined by Savickas (1997) as an individual having the readiness to cope with the predicable task of preparing for the adjustments, which are occasioned by changing work environments. Savickas and Porfeli (2012) have also linked career adaptability to professional duties, traumas, transitions and events with the majority of employees having to develop the strategies that are needed in order to cope and adapt. There are four global dimensions of career adaptability, namely (1) career concern, (2) career control, (3) career curiosity and (4) career confidence. These dimensions that are coined as adaptive readiness behaviour through the sub-dimensions of career concern, points to the plan fullness in relation to future careers, career control are feelings of self-determination, career curiosity, which amount to a degree of self-knowledge and career confidence, a significance of self-efficacy to deal with challenges and barriers (Savickas \& Porfeli, 2012).

The working environment is characterised by unpredictable and uncertain careers. The human capital performance in the Water and Sanitation Department is a determining factor in the department's overall success during challenging economic times. It is incumbent on employees to adjust and cope with the ongoing changes taking place in the department. In the Water and Sanitation Department, employees have become more responsible more than ever before for their own careers and in ensuring that they develop the skills required to remain employable. Employees are expected to become more flexible, efficient and adaptable to high demands when pursuing careers (Maree, 2013; Tolentino et al., 2014; Zacher et al., 2015). Research has revealed that individuals will redefine themselves through internal selfregulatory mechanisms in an effort to adapt to changing contexts (Coetzee, Schreuder, \& Tladinyane, 2014; De Guzman \& Choi, 2013).

Various definitions of emotional intelligence refer to an individual's ability to be aware of, to control and to express emotions and to deal with interpersonal relationships in an empathetic way (Salovey \& Mayer, 1990). Traditionally, many public sector employees tend to separate emotions from their work when it comes to decision-making (Salovey \& Mayer, 1990, Schutte et al., 1998). Societal expectations of the public sector are tied to individuals' emotions because of their trust in public service employees to provide a service. Studies have revealed that emotional intelligence plays a crucial role in explaining employees' job-related success (Schutte et al., 1998; Wong \& Law, 2002). Employees who possess the capability to understand and self-regulate their emotions and to motivate and empathise with others and who possess social skills may be more adaptable to their careers as compared with their counterparts (Schutte et al., 1998; Wong \& Law, 2002).

Emotional intelligence comprises the following four dimensions, namely perception of emotion, managing own emotion, managing others' emotion and the utilisation of emotion (Schutte et al., 1998). The perception of emotion refers to the ability to recognise one's emotions or those of others, and any other stimuli in our environment. Managing own emotions refers to the ability to handle and control selfemotions whilst managing others' emotions is explained as the ability to handle and control the emotions of others. Finally, the utilisation of emotions is the ability to use emotions effectively (Schutte et al., 1998).

It may be stated that gender plays a role in the Water and Sanitation Department in South Africa. For many years career paths of women and men differ in the public sector. There is very little representation of women aspiring for leadership positions, this could be because of organisational factors and deeply embedded societal norms (Bangani \& Vyas-Doorgapersad, 2020). In South Africa, the careers of women may be said to have been liberated after 1994 with the new labour legislation. The theoretical concepts of careers for woman and men in the public sector have proved to be socially constructed, in which women are traditionally marginalised and undervalued (Bimrose et al., 2014).

Research into the concepts of emotional intelligence and gender is based on social and emotional competence rather than on intellectual ability and personality (FernándezBerrocal, Cabello, Castillo, \& Extremera, 2012; Fischer, Kret, \& Broekens, 2018; Fischer \& Manstead, 2016). Empirical research point to woman being socialised differently as compared with men, as women tend to possess high empathy and are more aware of social responsibilities and interpersonal relationships as compared with men, who are portrayed as abstaining from expressing emotions, thus showing less 
emotions in a work environment (Fernández-Berrocal et al., 2012; Fischer et al., 2018; Fischer \& Manstead, 2016).

Based on the review of relevant literature, it was expected that the gender and emotional intelligence of individuals would significantly predict their career adaptability.

\section{Research design}

The research study involved a cross-sectional design that collected primary data using self-administered questionnaires. The internal consistency reliability was determined using Cronbach's alpha coefficients.

\section{Research method}

\section{Research participants}

The sample consisted of permanent employees $(n=160)$ in the Department of Water and Sanitation in South Africa, which consisted of 97 men and 63 women. Socio-demographic variables included race, gender, age, marital status, employment status, education level, job level and time in the current position.

\section{Measuring instruments}

A biographical questionnaire that included race, gender age, marital status, employment status, education level, job level, time in the current position was administered. The Emotional Intelligence Scale, developed by Schutte et al. (1998), was used to assess emotional intelligence. The scale comprises 33 items with four dimensions, namely perception of emotion, managing own emotions, managing others' emotions and the utilisation of emotion. Example of the test items included 'I expect that I will do well at most things I try' and 'Emotions are one of the things that make my life worth living'. The measure has been used in various studies and reported to demonstrate adequate psychometric properties. The Emotional Intelligence (EI) scale shows evidence of a good internal consistency reliability of 0.87 and was strongly validated using the Trait Metal Mood Scale (Schutte et al., 1998). A Cronbach's alpha of 0.86 was obtained for the scale in this study.

Career adaptability was measured using the 55-item Career Adaptability Inventory developed by Savickas and Porfeli (2012). It consisted of four dimensions, namely career concern, career control, career curiosity and career confidence. Responses to the items in the scale are based on a 5-point Likert scale that includes strongly disagree (score 1) to strongly agree (score 5). This implies that the higher the score, the higher the level of career adaptability in the respondents. Examples of test items included 'Realising that today's choices shape my future' and 'I am concerned about my career'. Maggiori, Johnston, Krings, Masoudi and Rossier (2013) and Savickas (2011) earlier reported a Cronbach's alpha of 0.88 for the entire scale. In this study a Cronbach's alpha of 0.95 was used for the scale.

\section{Research procedure and ethical considerations}

An electronic self-reported questionnaire was used to collect the requisite data from the participants. The research objectives were made known to both the management and the head of the Department of Water and Sanitation, South Africa. The researcher then sought for permission of the head of the Department of Water and Sanitation, South Africa to engage workers in a researcher exercise and this was granted. Their informed consent to participate in the study was sought directly from the employees of the department who were ensured that participation in the exercise was voluntary. The participants were given the opportunity to opt out of the exercise at will. The respondents were assured of the confidentiality of the information they provided and it was promised that this information would be used for research purposes only.

\section{Statistical analysis}

IBM $^{\circledR}$ SPSS $^{\circledR}$ (25 version) software was used to analyse the data collected in the study. The biographical data of the respondents was analysed using descriptive statistics such as the mean, standard deviation, frequency distribution and percentages. The variables under study included gender, which was dichotomised into male and female (male coded 0 and female coded 1) and emotional intelligence (perception of emotion, managing own emotions, managing others' emotions and utilisation of emotion) and career adaptability (career concern, career control, career curiosity and career confidence). In order to achieve the research objective, the bivariate correlation as a preliminary analysis established the relationships between all relevant variables in the study. The hierarchical multiple regression was computed in order to determine the independent and joint contributions of the predictor variables in the criterion variables (career adaptability). Certain assumptions were considered before the use of hierarchical multiple regression as an appropriate statistic for the study. Firstly, we established the sample size based on the assumption that a minimum of 96 participants was considered adequate as a sample for five predictor variables in hierarchical multiple regression (Tabachnick \& Fidell, 2001). Thus, the sample size in this study (160) exceeded the minimum of 96 . Secondly, we ensured that the significant coefficients between the predictor variables and criterion variable (career adaptability) in the bivariate correlation were moderately related and not strongly correlated and this could have indicated singularity in relation to the predictor variables. All these steps were taken to affirm the appropriateness of the use of hierarchical multiple regression. All results were significant at either $p<0.05$ or 0.01 .

\section{Ethical considerations}

Institutional approval to conduct the study was obtained from the Department of Industrial and Organisational Psychology, University of South Africa. The authors declare 
that the study has been carried out strictly in accordance with the Policy for Research Ethics of the University of South Africa (UNISA). The authors took great care to ensure that the research was conducted with the highest integrity, taking into account UNISA's Policy for Infringement and Plagiarism. Ethical clearance number: 2018_CEMS/IOP_010.

\section{Results}

\section{Descriptive statistics and bivariate correlation results}

The mean, standard deviations, internal consistency reliabilities and bivariate correlations are reported in Table 1.

A composite Cronbach's alpha of emotional intelligence was at a coefficient of 0.86 , which indicates the high internal reliability of the scale. The subscales were found to have 0.69 (perception of emotion), 0.50 (managing own emotion), 0.71 (managing others' emotion) and 0.67 (utilisation of emotion), respectively, suggesting moderate internal reliability for managing own emotions. According to Sekaran (2000), a coefficient that is less than 0.6 shows moderate reliability. The overall career adaptability scale was found to have a Cronbach's alpha coefficient of 0.95 . The subscales were calculated as 0.88 (concern), 0.87 (control), 0.93 (curiosity) and 0.92 (confidence), respectively, thus suggesting a strong internal reliability coefficients.

The bivariate correlation results reveal that total emotional intelligence correlated significantly $(r=0.83, p<0.01)$, with career adaptability $(r=-0.28, p<0.01)$. The sub-dimensions of emotional intelligence, namely managing own emotions $(r=0.58, p<0.01)$, correlated significantly with the subdimension of career adaptability career concern $(r=0.39$, $p<0.01)$, career control, $(r=0.32, p<0.01)$, career curiosity, $(r=0.35, p<0.01)$, career confidence $(r=0.24, p<0.01)$ and managing others emotions with sub-dimension of career adaptability, career concern $(r=0.61, p<0.01)$, career control, $(r=0.62, p<0.01)$, career curiosity, $(r=0.54, p<0.01)$, career confidence $(r=0.53, p<0.01)$, utilisation of emotions with sub-dimension of career adaptability, career concern $(r=0.33, p<0.01)$, career control, $(r=0.38, p<0.01)$, career curiosity, $(r=0.35, p<0.01)$, career confidence $(r=0.36$, $p<0.01)$,

\section{Regression analysis}

In order to assess whether individuals' gender and emotional intelligence positively and significantly predicted their career adaptability, five stepwise regression models were performed (see Table 2).

In order to achieve the study's objective, we computed a five-model hierarchical multiple regression using career adaptability as an outcome variable and gender alongside the four dimensions of emotional intelligence as predictors. The results are presented in Table 2, which revealed a significant negative association with career adaptability and contributed to the regression model $\mathrm{F}(1,158)=13.51$, $p<0.01$ by accounting for $8 \%$ of the variation in career adaptability. In the second model, perception of emotion was added and the result indicated a positive association with career adaptability and contributed to the regression model $\mathrm{F}(2,157)=18.60, p<0.01$, with an increase of $9 \%$ of the variation in career adaptability. Managing own emotion was included in the third model with the result showing a positive association with career adaptability and contributing significantly to the regression model $\mathrm{F}$ $(3,156)=31.24, p<0.01$, which led to an increase of $18 \%$ in the variance of career adaptability. With the addition of managing others' emotion in fourth model, the result showed a positive association with career adaptability and contributed slightly to the regression model $F$ $(4,155)=25.12, p<0.01$, which led to an increase of $2 \%$ in the variance of career adaptability. Utilisation of emotion was added to the fifth model but showed no significant association but jointly predicted the regression model $\mathrm{F}$ $(1,154)=20.02, p<0.01$, at a $0 \%$ variance of career adaptability. Although all the predictor variables jointly predicted career adaptability at 39\%, managing own emotion accounted for $18 \%$ of this prediction, followed by perception of emotion (11\%), then gender $(8 \%)$ and

TABLE 1: Bivariate correlations, mean and standard deviations between all variables $(N=160)$.

\begin{tabular}{|c|c|c|c|c|c|c|c|c|c|}
\hline Variable & 1 & 2 & 3 & 4 & 5 & 6 & 7 & 8 & 9 \\
\hline Emotional intelligence & $0.83 * *$ & - & - & - & - & - & - & - & - \\
\hline Perception of emotion & 0.00 & - & - & - & - & - & - & - & - \\
\hline Managing own emotions & -0.11 & $0.58 * *$ & - & - & - & - & - & - & - \\
\hline Managing others' emotion & -0.14 & $0.47 * *$ & $0.46 * *$ & - & - & - & - & - & - \\
\hline Utilisation of emotion & $-0.16^{*}$ & $0.51 * *$ & $0.64 * *$ & $0.68 * *$ & - & - & - & - & - \\
\hline Career adaptability & $-0.28 * *$ & $0.34 * *$ & $0.57 * *$ & $0.40 * *$ & $0.46 * *$ & - & - & - & - \\
\hline CA-Concern & $0.57 * *$ & $0.39 * *$ & $0.61 * *$ & $0.33 * *$ & $0.58 * *$ & $0.76 * *$ & - & - & - \\
\hline CA-Control & $0.53 * *$ & $0.32 * *$ & $0.62 * *$ & $0.38 * *$ & $0.46 * *$ & $0.90 * *$ & $0.74 * *$ & - & - \\
\hline CA-Curiosity & $0.50 * *$ & $0.35 * *$ & $0.54 * *$ & $0.35 * *$ & $0.41 * *$ & $0.96 * *$ & $0.67 * *$ & $0.84 * *$ & - \\
\hline CA-confidence & $0.43 * *$ & $0.24 * *$ & $0.53 * *$ & $0.36 * *$ & $0.33 * *$ & $0.95 * *$ & $0.63 * *$ & $0.85 * *$ & $0.91 * *$ \\
\hline$M$ & 0.39 & 36.29 & 34.13 & 30.95 & 23.82 & 199.75 & 199.74 & 41.15 & 40.70 \\
\hline SD & 0.49 & 5.19 & 3.88 & 4.12 & 3.20 & 35.98 & 41.15 & 40.70 & 39.92 \\
\hline$\alpha$ & 0.86 & 0.69 & 0.50 & 0.67 & 0.95 & 0.88 & 0.87 & 0.93 & 0.92 \\
\hline
\end{tabular}

$*, p \leq 0.05$ statistically significant; **, $p \leq 0.01$, statistically significant; ***, $p \leq 0.001$, statistically significant.

$\mathrm{M}$, mean; SD, standard deviation; CA, career adaptability; $\alpha$, Cronbach's Alpha. 
TABLE 2: Five-model hierarchical multiple regression analysis of gender and emotional intelligence dimensions predicting career adaptability $(N=160)$.

\begin{tabular}{|c|c|c|c|c|c|c|c|c|c|c|c|c|c|c|c|}
\hline \multirow[t]{2}{*}{ Variable } & \multicolumn{3}{|c|}{ Model 1} & \multicolumn{3}{|c|}{ Model 2} & \multicolumn{3}{|c|}{ Model 3} & \multicolumn{3}{|c|}{ Model 4} & \multicolumn{3}{|c|}{ Model 5} \\
\hline & B & SEB & $\beta$ & B & SEB & $\beta$ & B & SEB & $\beta$ & B & SEB & $\beta$ & B & SEB & $\beta$ \\
\hline Gender & -20.61 & 5.61 & $-0.28 * *$ & -20.66 & 5.27 & $-0.28 * *$ & -16.17 & 4.69 & $-0.22 * *$ & -14.87 & 4.68 & $-0.20 * *$ & -14.71 & 4.71 & $-0.20 * *$ \\
\hline $\begin{array}{l}\text { Perception of } \\
\text { emotion }\end{array}$ & - & - & - & 2.33 & 0.50 & $0.34 * *$ & 0.17 & - & - & -0.18 & 0.56 & -0.03 & -0.20 & 0.56 & -0.03 \\
\hline Own emotion & - & - & - & - & - & - & 4.94 & - & 0.02 & 4.55 & - & - & 4.41 & 0.82 & $0.48 * *$ \\
\hline Others' emotion & - & - & - & - & - & - & - & 0.54 & $0.53 * *$ & 1.39 & 0.74 & $0.49 * *$ & 1.23 & 0.77 & 0.14 \\
\hline $\begin{array}{l}\text { Utilisation. of } \\
\text { emotion }\end{array}$ & - & - & - & - & - & - & - & 0.73 & - & - & 0.65 & $0.16 *$ & 0.45 & 1.12 & 0.04 \\
\hline$R$ & - & 0.28 & - & - & 0.44 & - & - & 0.61 & - & - & 0.63 & - & - & 0.63 & - \\
\hline$R^{2}$ & - & 0.08 & - & - & 0.19 & - & - & 0.37 & - & - & 0.39 & - & - & 0.39 & - \\
\hline $\operatorname{Adj} R^{2}$ & - & 0.07 & - & - & 0.18 & - & - & 0.36 & - & - & 0.38 & - & - & 0.37 & - \\
\hline$R^{2}$ change (\%) & - & 0.08 & - & - & 0.11 & - & - & 0.18 & - & - & 0.02 & - & - & 0.00 & - \\
\hline$F$ & - & $13.51 * *$ & - & - & $18.60 * *$ & - & - & $31.24 * *$ & - & - & $25.12 * *$ & - & - & $20.02 * *$ & - \\
\hline$F$ change & - & $13.51 * *$ & - & - & $21.91 * *$ & - & - & $45.87 * *$ & - & - & $4.61 *$ & - & - & 0.16 & - \\
\hline
\end{tabular}

Note: Standardised beta $(\beta)$ weights are reported for the final step in each model. Criterion variable - Career adaptability.

$\mathrm{B}$, unstandardised coefficient; $\mathrm{SEB}$, standard error of the computed value of $\mathrm{B} ; \beta$, standardised coefficient; $R$, correlation between the observed value and the predicted value of career adaptability; $R^{2}$, square of $R ; \mathrm{F}$, ratio of the mean regression; $\operatorname{Adj} R^{2}$, adjusted $R^{2}$

${ }^{*}, p \leq 0.05$ statistically significant; ${ }^{* *}, p \leq 0.01$, statistically significant; ${ }^{* * *}, p \leq 0.001$, statistically significant.

TABLE 3: Results of Mann-Whitney $U$ test showing significant mean differences between women and men regarding career adaptability.

\begin{tabular}{lccccc}
\hline Variables & $\begin{array}{c}\text { Mann- } \\
\text { Whitney U }\end{array}$ & Z & $\boldsymbol{p}$ & $\begin{array}{c}\text { Mean (SD) } \\
\text { Women }{ }^{\dagger}\end{array}$ & $\begin{array}{c}\text { Mean (SD) } \\
\text { Men } \neq\end{array}$ \\
\hline Career concern & 2388.000 & -2.330 & 0.019 & 69.900 & 87.380 \\
Career control & 2656.000 & -1.400 & 0.162 & 74.160 & 84.620 \\
Career curiosity & 2012.000 & -3.660 & 0.000 & 63.940 & 91.260 \\
Career confidence & 1516.000 & -5.390 & 0.000 & 56.060 & 96.370 \\
\hline
\end{tabular}

SD, standard deviation.

$\dagger$, Women: $n=63 ;+$, Men: $n=97$.

$*, p \leq 0.05$ statistically significant; **, $p \leq 0.01$ - statistically significant; ***, $p \leq 0.001$ statistically significant.

managing others' emotion (2\%). There was, however, nothing significant in the direct contribution of utilisation of emotions.

\section{Test for significant mean difference: Gender}

A Mann-Whitney U test (depicted in Table 3) indicated the significant mean difference between men and women.

The Mann-Whitney U test was applied to test whether there were differences in the dimensions of career adaptability between male and female workers. Specifically, the career concern scores for male workers (mean rank $=87.38$ ) and female workers (mean rank $=69.90$ ) were statistically different with $U=2388.00, Z=-2.33, p=0.019(<0.05)$. The career control scores for male workers (mean rank $=84.62$ ) and female workers (mean rank $=74.16$ ) were not statistically different with $U=2656.00, Z=-1.40, p=0.162$ (> 0.05) whilst the career curiosity scores for male workers (mean rank $=91.26$ ) and female workers (mean rank $=63.94$ ) were statistically different with $U=2012.00, Z=-3.66, p=0.000$ $(<0.01)$. The career confidence scores for male workers (mean rank $=96.37$ ) and female workers (mean rank $=56.06$ ) were statistically different with $U=1516.00, Z=-5.39$, $p=0.000(<0.01)$.

\section{Discussion}

The aim of the study was to explore whether gender and emotional intelligence positively predicted career adaptability amongst employees of the Department of
Water and Sanitation in South Africa. The findings revealed that all the predictor variables jointly explained the career adaptability and gender of the employees. The joint contribution accounted substantially for 39\% in explaining the career adaptability amongst the employees with managing own emotions recording the highest score in relation to the contribution. This finding suggests that gender and the three dimensions of emotional dimensions, namely managing own emotions, perceptions of emotions and managing other emotions, are relevant to a large extent in explaining career-related coping behaviour. Various research studies have proved that emotional intelligence endows individuals with a higher adaptive functioning than may otherwise have been the case (Celik \& Storme, 2017; Coetzee \& Harry, 2014; Ismail, 2017; Udayar, Fiori, Thalmayer, \& Rossier, 2018) with emotional intelligence being regarded as a psychological resource on which employees may rely on in times of career uncertainty. Research has proved that emotional intelligence is important as a factor of the general adaptive readiness in which individuals rely in order to mobilise the career adaptability resources that may lead to adaptive functioning (Cizel, 2018; Parmentier, Prirsoul, \& Nils, 2019).

Managing own emotions predicted career adaptability to a greater extent than the other sub-dimensions of emotional intelligence, which implies that individuals in the Water and Sanitation Department possess the ability and the readiness to respond to change. However, research has shown that general emotional intelligence alone is not sufficient to achieve success in life as both career adaptability and managing own emotions are self-regulatory strategies that serve as important psychosocial resources in both personal and environment interaction (Le, Hamzah, \& Omar, 2019; Savickas \& Porfeli, 2012).

The results also revealed a significant negative relationship between gender and the emotional intelligence sub-dimension of utilising emotions. The literature highlights the popular belief that men and woman interpret emotions in different 
ways with woman being more adept interpersonally than men whereas men are more optimistic and self-confident in terms of utilising their emotions (Ahmadi, 2015; Nikoopour \& Esfandiari, 2017). Socialisation between men and women is different with personality characteristics explaining why woman are more empathetic and socially responsible in interpersonal relationships as compared with men. In relation to the utilisation of emotions, woman tend to be more expressive and assertive whereas men tend to control their feelings and, in most instances, they refrain from expressing their emotions (Ahmadi, 2015; Nikoopour \& Esfandiari, 2017).

Independently, a significant negative association was found between gender and career adaptability which implies that women (lower mean scores as compared with men) found it more difficult to use adaptive strategies in their work roles compared with men. Adaptation to new opportunities involves motivation and goals that are guided by both inner needs and external opportunities in order to reinforce the aspirations which, as revealed in the research, appeared to be lacking amongst the women in the Water and Sanitation Department in South Africa (Han \& Rojewski, 2015; Osittuyo, 2018; Savickas \& Porfeli, 2012; Tolentino et al., 2014). The development of metacompetencies has become a crucial coping mechanism, especially in a world of unpredictability on an emotional level. Research has highlighted that individuals rely on emotional intelligence and career adaptabilities in order to respond to career changes (Di Fabio \& Saklofske, 2014; Savickas, 1997, 2005).

\section{Conclusion}

Based on the study's findings, it was concluded that male employees who possess the abilities to be aware, use and manage their emotions and those of others are more adaptable in their careers. In the light of the paucity of research on gender in the African context, it may be said that this study has contributed to the existing body of knowledge on emotional intelligence as a predictor of employees' career adaptability and gender differences. Both emotional intelligence and career adaptability are important metacompetencies that foster the adaptive behaviour that facilitates adaptation to career challenges and promotes individual wellness (Parmentier et al., 2019). These constructs are regarded as malleable competencies that may be learned through training, which may result in empirically driven work interventions.

\section{Limitations and directions for future}

The study focused primarily on employees in the Water and Sanitation Department in South Africa. The sample comprised mainly of permanently employed public service employees. The constructs of the study used self-reports. There may have been bias because of the common methods variance. Although the study was cross-sectional, it was not possible to ascertain the causal direction between the variables. The replication of the study in other work contexts is needed if the study's findings are to be generalised. Nevertheless, notwithstanding these limitations, the study highlighted the importance of taking into account emotional intelligence in the career developmental processes in the future. Future research should be conducted to investigate the role of emotion in career development whilst the study of the emotional manifestations regarded as self-regulatory resources may enhance an individual's use of their metacompetencies in responding to career-related tasks.

\section{Acknowledgements Competing interests}

The authors declare that they have no financial or personal relationships that may have inappropriately influenced them in the writing of this article.

\section{Authors' contributions}

N.H. was responsible for the literature review, manuscript preparation and review of the final manuscript. T.M. was responsible for data collection, the statistical analysis and interpretation of the results.

\section{Funding information}

This research received no specific grant from any funding agency in the public, commercial or not-for-profit sectors.

\section{Data availability}

The authors confirm that the data supporting the findings of this study are available within the article.

\section{Disclaimer}

The views and opinions expressed in this article are those of the authors and do not necessarily reflect the official policy or position of any affiliated agency of the authors.

\section{References}

Ahmadi, A.S. (2015). Gender differences in emotional content of EFL written narratives. Journal of Language Teaching and Research, 6(3), 619. https://doi. org/10.17507/jltr.0603.19

Ambiel, R.A.M., De Carvalho, L.F., Martins, G.H., \& Tofoli, L. (2016). Comparing the adaptabilities of Brazilian adolescent students and adult workers. Journal of Vocational Behaviour, 94, 20-27. https://doi.org/10.1016/j.jvb.2016.02.005

Bangani, A., \& Vyas-Doorgapersad, S. (2020). The implementation of gender equality within the South African public service (1994-2019). Africa's Public Service Delivery \& Performance Review, 8(1), a353. https://doi.org/10.4102/apsdpr.v8i1.353

Bimrose, J., Watson, M., McMahon, M., Haasler, S., Tomassini, M., \& Suzanne, P.A. (2014). The problem with women? Challenges posed by gender for career guidance practice. International Journal for Educational and Vocational Guidance, 14(1), 77-88. https://psycnet.apa.org/doi/10.1007/s10775-013-9256-9

Brown, S.D., \& Lent, R. (2016). Vocational psychology: Agency, equity and well-being Annual Review of Psychology, 67(1), 541-565. https://doi.org/10.1146/annurevpsych-122414-033237

Celik, P., \& Storme, M. (2017). Trait emotional intelligence predicts academic satisfaction through career adaptability. Journal of Career Assessment, 26(4), 666-677. https://doi.org/10.1177/1069072717723290

Cizel, R. (2018). Gender and emotional intelligence as predictors of tourism faculty students' career adaptability. Advances in Hospitality and Tourism Research (AHTR), 6(2), 188-204. https://doi.org/10.30519/ahtr.431014

Coetzee, M., \& Harry, N. (2014). Emotional intelligence as a predictor of employees career adaptability. Journal of Vocational Behavior, 84(1), 90-97. https://doi. org/10.1016/j.jvb.2013.09.001 
Coetzee, M., Schreuder, D., \& Tladinyane, R. (2014). Employees' work engagement and job commitment: The moderating role of career anchors. SA Journal of Human Resource Management, 12(1), a572. https://doi.org/10.4102/sajhrm v12i1.572

De Guzman, A.B., \& Choi, K. (2013). The relations of employability skills to caree adaptability among technical school students. Journal of Vocational Behavior 82(3), 199-207. https://doi.org/10.1016/j.jvb.2013.01.009

Di Fabio, A., \& Saklofske, D.H. (2014). Comparing ability and self-report trait emotional intelligence, fluid intelligence, and personality traits in career decision. Personality and Individual Differences, 64, 174-178. https://doi.org/10.1016/j. paid.2014.02.024

Duffy, R.D. (2010). Sense of control and career adaptability among undergraduate students. Journal of Career Assessment, 18(4), 420-430. https://doi.org/10.1177/ 1069072710374587

Fernández-Berrocal, P., Cabello, R., Castillo, R., \& Extremera, N. (2012). Gender differences in emotional intelligence: The mediating effect of age. Behavioral Psychology/Psicología Conductual: Revista Internacional Clínica y de la Salud, 20(1), 77-89.

Ferreira, N. (2012). Hardiness in relation to organisational commitment in the human resource management field. SA Journal of Human Resource Management, 10(2) 1-10. https://doi.org/10.4102/sajhrm.v10i2.418

Fischer, A.H., Kret, M.E., \& Broekens, J. (2018). Gender differences in emotion perception and self-reported emotional intelligence: A test of the emotion sensitivity hypothesis. PLOS One, 13(1), e0190712. https://doi.org/10.1371/ journal.pone.0190712

Fischer, A.H. \& Manstead, A.S.R. (2016). The social function of emotion and emotion regulation. In M. Lewis, J. Haviland-Jones, \& L.F. Barrett (Eds.), Handbook of emotions (4th edn., pp. 2-27). New York, NY: Guilford.

Han, H., \& Rojewski, J.W. (2015). Gender specific models of work-bound Korean adolescents' social supports and career adaptability on subsequent job satisfaction. Journal of Career Development, 42(2), 149-164. https://doi. org/10.1177/0894845314545786

Ineson, E.M., Benke, E., \& Laszlo, J. (2013). Employee loyalty in Hungarian hotels. International Journal of Hospitality Management, 32, 31-39. https://doi. org/10.1016/j.ijhm.2012.04.001

Ismail, S. (2017). Graduate employability capacities, self-esteem and caree adaptability among South African young adults. SA Journal of Industrial Psychology, 43(1), 1-10. https://doi.org/10.4102/sajip.v43i0.1396

Le, K.K., Hamzah, S.R., \& Omar, Z. (2019). Conceptualising personal resources on career adaptability. International Journal of Academic Research in Business and Social Sciences, 9(9), 875-886. https://doi.org/10.6007/IJARBSS/v9i9/6378

Lee, Y.H. (2019). Emotional intelligence, servant leadership, and development goa orientation in athletic directors. Sport Management Review, 22(3), 395-406. https://doi.org/10.1016/j.smr.2018.05.003

Maggiori, C., Johnston, C.S., Krings, F., Massoudi, K., \& Rossier, J. (2013). The role of career adaptability and work conditions on general and professional well-being. Journal of Vocational Behaviour, 83(3), 437-449. https://doi.org/10.1016/j. jvb.2013.07.001
Maree, J.G. (2013). Latest developments in career counselling in South Africa: Towards a positive approach. South African Journal of Psychology, 43(4), 409-421. https:// doi.org/10.1177/0081246313504691

Nikoopour, J., \& Esfandiari, N. (2017). The relationship between emotional, social, cultural, spiritual intelligence and EFL teachers' teaching effectiveness. Journal of Language Teaching and Research, 8, 138-148. https://doi.org/10.17507/jttr.0801.17

Osituyo, D. (2018). Underrepresentation and career advancement of women in the South African public-sector setting. International Journal of Women's Studies, 19(3), 171-186.

Parmentier, M., Pirsoul, T., \& Nils, F. (2019). Examining the impact of emotional intelligence on career adaptability: A two-wave cross-lagged study. Personality and Individual Differences, 151, 109446. https://doi.org/10.1016/j.paid.2019.05.052

Salovey, P., \& Mayer, J.D. (1990). Emotional intelligence. Imagination, Cognition and Personality, 9(3), 185-211. https://doi.org/10.2190/DUGG-P24E-52WK-6CDG

Savickas, M.L. (1997). Career adaptability: An integrative construct for life-span, lifespace theory. Career Development Quarterly, 45(3), 247-259. https://doi. org/10.1002/j.2161-0045.1997.tb00469.x

Savickas, M.L. (2005). The theory and practice of career construction. In S.D. Brown \& R.W. Lent (Eds.), Career development and counseling: Putting theory and research to work (pp. 42-70). Hoboken, NJ: John Wiley \& Sons.

Savickas, M.L. (2011). Career counselling. Washington, DC: American Psychological Association.

Savickas, M.L. (2012). Life design: A paradigm for career intervention in the 21st century. Journal of Counselling \& Development, 90(1), 13-19. https://doi. org/10.1111/j.1556-6676.2012.00002.x

Savickas, M.L., \& Porfeli, E.J. (2012). Career adapt-abilities scale: Construction, reliability, and measurement equivalence across 13 countries. Journal of Vocational Behaviour, 80, 661-673. https://doi.org/10.1016/j.jvb.2012.01.011

Schutte, N.S., Malouff, J.M., Hall, L.E., Haggerty, D.J., Cooper, J.T., Golden, C.J., \& Dornheim, L. (1998). Development and validation of a measure of emotional intelligence. Personality and Individual Differences, 25, 167-177. https://doi. org/10.1016/S0191-8869(98)00001-4

Sekaran, U. (2000). Research methods for business. New York, NY: John Wiley \& Sons.

Tabachnick, B.G., \& Fidell, L.S. (2001). Using multivariate statistics (4th edn.). Needham Heights, MA: Allyn \& Bacon.

Tolentino, L.R., Raymund, P., Garcia, J.M., Nhat, V., Lloyd, S., Restubog, D., ... Plewa, C. (2014). Career adaptation: The relation of adaptability to goal orientation, proactive personality, and career optimism. Journal of Vocational Behavior, 84(1) 39-48. https://doi.org/10.1016/j.jvb.2013.11.004

Udayar, S., Fiori, M., Thalmayer, A.G., \& Rossier, J. (2018). Investigating the link between trait emotional intelligence, career indecision, and self-perceived employability: The role of career adaptability. Personality and Individual Differences, 135, 7-12. https://doi.org/10.1016/j.paid.2018.06.046

Wong, C.S., \& Law, K.S, (2002). The effects of leader and follower emotional intelligence on performance and attitude: An exploratory study. Leadership Quarterly, 13, 243-274. https://doi.org/10.1016/S1048-9843(02)00099-1

Zacher, H., Ambiel, R.A., \& Noronha, A.P.P. (2015). Career adaptability and career entrenchment. Journal of Vocational Behaviour, 88, 164-173. https://doi. org/10.1016/j.jvb.2015.03.006 